\title{
Pengaruh Tayangan Youtube Podcast Deddy Corbuzier terhadap Kepercayaan Penonton pada Vaksin Covid 19
}

\author{
*Adinda Salsa Bella Chandra Dewi, Indri Rachmawati \\ Prodi Manajemen Komunikasi, Fakultas Ilmu Komunikasi, Universitas \\ Islam Bandung, Indonesia. \\ *dindasbcd@gmail.com, indri.rachmawati@unisba.ac.id
}

\begin{abstract}
The Covid 19 pandemic occurred in Indonesia, many conspiracy theories have emerged which have been widely discussed by Youtubers in Indonesia. Deddy Corbuzier is now in 3rd position as the richest YouTuber in Indonesia. Deddy Corbuzier often makes video podcasts discussing the Covid 19 conspiracy. One of his videos that is widely discussed is his interview with former Minister of Health, Siti Fadilah. In the video, according to him, the H1N1 virus is a political and economic conspiracy from Bill Gates, who is a global elite and this could have happened in Covid 19. The research entitled "The Effect of Deddy Corbuzier's Youtube Podcast on Audience Trust in the Covid 19 Vaccine", has the formulation of the problem whether the Deddy Corbuzier episode of Siti Fadilah's podcast has an effect on audience confidence in the Covid 19 vaccine. The purpose of this study is to understand the effect of these shows on audience confidence in the Covid 19 vaccine. This study uses a quantitative method with an online questionnaire. Data analysis was performed using a simple linear regression analysis method and was calculated using the SPSS application. The results showed that there was a significant effect of the YouTube podcast on audience confidence in the Covid 19 vaccine. This means that the audience trusts Deddy Corbuzier's YouTube podcast so that the audience also believes that the vaccine that Bill Gates handled is a political and economic conspiracy of the ruler of the world.
\end{abstract}

Keywords: Youtube podcast, Siti Fadilah, Interactivity, Student, Covid 19 vaccine.

\begin{abstract}
Abstrak. Pandemi Covid 19 terjadi di Indonesia, teori konspirasi banyak bermunculan yang kemudian banyak dibahas oleh Youtuber di Indonesia. Deddy Corbuzier kini menempati posisi ke-3 sebagai Youtuber terkaya di Indonesia. Deddy Corbuzier kerap kali membuat video podcast yang membahas mengenai konspirasi Covid 19. Salah satu videonya yang banyak diperbincangkan adalah wawancaranya dengan mantan MenKes Siti Fadilah. Dalam video tersebut, Menurutnya, virus H1N1 merupakan konspirasi politik dan ekonomi dari Bill Gates yang merupakan elite global dan hal tersebut bisa saja terjadi di Covid 19. Penelitian dengan judul "Pengaruh Tayangan Youtube Podcast Deddy Corbuzier terhadap Kepercayaan Penonton pada Vaksin Covid 19", memiliki rumusan masalah apakah tayangan podcast Deddy Corbuzier episode Siti Fadilah berpengaruh terhadap kepercayaan penonton pada vaksin Covid 19. Tujuan penelitian ini adalah memahami pengaruh tayangan tersebut terhadap kepercayaan penontonnya pada vaksin Covid 19. Penelitian ini menggunakan metode kuantitatif dengan kuesioner online. Data analisa dilakukan dengan menggunakan metode analisis regresi linear sederhana dan dihitung menggunakan aplikasi SPSS. Hasil penelitian menunjukkan bahwa terdapat pengaruh yang signifikan dari tayangan youtube podcast terhadap kepercayaan penonton pada vaksin Covid 19. Hal ini berarti bahwa penonton mempercayai tayangan youtube podcast Deddy Corbuzier sehingga penonton juga percaya bahwa vaksin yang dicampur tangani oleh Bill Gates merupakan konspirasi politik dan ekonomi dari para penguasa dunia.
\end{abstract}

Kata Kunci: Youtube podcast, Siti Fadilah, Interaktivitas, Mahasiswa, Vaksin Covid 19 


\section{A. Pendahuluan}

Kini media sosial seolah menjadi kebutuhan pokok bagi masyarakat. Survei dari wearesocial.com menyatakan bahwa pengguna internet di Indonesia awal tahun 2020 sebanyak 175,4 juta dengan total populasi 272,1 juta jiwa. Hal ini menunjukkan pertambahan pengguna internet dari tahun sebelumnya sekitar $17 \%$ atau 25 juta. Sementara itu, pengguna media sosial di Indonesia berjumlah 160 juta pada awal januari 2020, meningkat 8,1\% atau sekitar 12 juta dari tahun sebelumnya. Sejak Covid 19 muncul di dunia pada akhir tahun 2019 silam dan bulan Maret 2020 di Indonesia, masyarakat semakin erat dengan media sosial. Berdasarkan data YouGov yang dikutip dari Facebook for Business, penggunaan media sosial di Asia Tenggara naik hampir $40 \%$. Hal ini karena masyarakat lebih banyak diam di rumah untuk menekan penyebaran Covid 19. Media sosial menjadi pelarian masyarakat dari kecemasannya terhadap Covid 19 yang saat ini tengah terjadi . Media sosial yang paling sering digunakan adalah Youtube. Dalam hasil survei wearesocial.com, Youtube termasuk ke dalam 10 media sosial yang sering digunakan di tahun 2020 (survei dilakukan bulan Januari - Februari 2020). Data terbaru dari survei wearesocial.com pada bulan Januari - Februari 2021, youtube tetap menjadi 10 media sosial yang sering digunakan.

Podcast saat ini menjadi salah satu konten Youtube yang banyak disaksikan oleh pengguna media sosial. Berdasarkan survei dari suarane.org pada tahun 2019 lalu, pendengar podcast di Indonesia berasal dari pulau Jawa dengan usia $21-25$ tahun. Teori konspirasi Covid 19 banyak bermunculan dan banyak dibahas oleh Youtuber di Indonesia. Deddy Corbuzier merupakan artis yang kini memiliki channel Youtube dan menempati posisi ke-3 sebagai Youtuber terkaya di Indonesia. Salah satu videonya yang banyak diperbincangkan adalah ketika ia berdialog dengan mantan menteri kesehatan Indonesia. Dalam video tersebut, Siti Fadilah membagikan ceritanya menangani virus H1N1 di Indonesia yang berdampak bagi dunia. Menurutnya, virus tersebut merupakan konspirasi politik dan ekonomi dari Bill Gates yang merupakan elite global dan hal tersebut bisa saja terjadi di Covid 19. Masyarakat kini skeptis terhadap vaksin Covid 19 karena pemberian vaksin yang seolah memaksa. Salah satu contohnya adalah dengan adanya peraturan daerah penanggulangan Covid 19 DKI Jakarta yang memberlakukan denda kepada warga yang menolak disuntik vaksin Covid 19 .

Penelitian ini memiliki rumusan masalah apakah tayangan podcast Deddy Corbuzier episode Siti Fadilah berpengaruh terhadap kepercayaan penonton pada vaksin Covid 19. Identifikasi masalah dari penelitian in adalah apakah terdapat pengaruh dari tayangan youtube podcast Deddy Cobruzier terhadap kepercayaan penonton pada vaksin Covid 19 dengan 5 dimensi dari interaktivitas yaitu arah komunikasi, fleksibilitas waktu dan peran yang dipertukarkan, kesadaran akan ruang dalam lingkungan komunikasi, tingkat pengendalian, dan tujuan yang diamati.

\section{B. Metodologi Penelitian}

Pendekatan kuantitatif dipilih karena peneliti menganalisis data-data hasil temuan guna mengetahui hubungan dari kedua variabel tersebut. Peneliti juga memilih analisis regresi linier sederhana karena dianggap sangat cocok untuk menjelaskan pengaruh dari tayangan Podcast Deddy Corbuzier di Youtube terhadap kepercayaan penonton pada vaksin Covid 19. Metode survei yang akan dilakukan peneliti adalah dengan menggunakan angket secara online atau google form yang akan disebar kepada subjek penelitian peneliti. Penelitian ini menggunakan survei online karena tengah berada dalam masa pandemi Covid 19 yang mengharuskan masyarakat bekerja dari rumah dan kondisi tersebut tidak memungkinkan untuk peneliti melakukan survei secara langsung.

\section{Hasil Penelitian dan Pembahasan}

Penelitian ini menganalisis hasil pengujian melalui data yang diperoleh meng gunakan kuesioner daring kepada mahasiswa 4 fakultas di Unisba (Dakwah, Tarbiyah, Ilmu Komunikasi, Psikologi) dengan tujuan mengetahui apakah terdapat pengaruh dari variabel $\mathrm{X}$ yaitu tayangan youtube podcast Deddy Corbuzier terhadap variabel Y yaitu kepercayaan penonton pada vaksin Covid 19. Pada variabel $\mathrm{X}$ terdapat 5 dimensi yaitu arah komunikasi, fleksibilitas waktu dan 
peran yang dipertukarkan, memiliki kesadaran akan ruang dalam lingkungan komunikasi, tingkat pengendalian (pada lingkungan komunikasi), dan tujuan yang diamati (pertukaran dan persuasi yang terarah). Dalam masing-masing dimensi peneliti mengajukan beberapa pernyataan pada kuesioner. Total sampel pada penelitian ini berjumlah 98 responden, namun peneliti membulatkan menjadi 100 responden.

Guna membuktikan bahwa tayangan youtube podcast Deddy Corbuzier episode Siti Fadilah mempengaruhi kepercayaan penonton pada vaksin Covid 19, peneliti melakukan uji regresi linear sederhana dan analisis dari hasil kuesioner penelitian yang telah disebarkan pada penonton yang berasal dari mahasiswa fakultas Psikologi, Dakwah, Tarbiyah, dan Ilmu Komunikasi di Unisba. Hasil penelitian menunjukkan bahwa terdapat pengaruh dari tayangan youtube podcast Deddy Corbuzier terhadap kepercayaan penonton pada vaksin Covid 19. Pada hasil penghitungan data didapatkan $\mathrm{R}$ square sebesar 0,473 yang berarti pengaruh variabel bebas atau tayangan youtube podcast Deddy Corbuzier terhadap variabel terikat atau kepercayaan penonton sebesar $47,3 \%$ sementara $51,7 \%$ adalah faktor-faktor lain yang tidak dibahas dalam penelitian ini. Selain itu berdasarkan hasil uji regresi pada variabel $X$ terdapat hasil 0,430 dan bernilai positif. Hal ini berarti setiap penambahan $1 \%$ nilai tayangan youtube podcast Deddy Corbuzier maka nilai kepercayaan penonton pada vaksin Covid 19 juga bertambah sebesar 0,430 . Selain itu nilai $R$ menunjukkan angka 0,688 yang artinya terdapat hubungan yang cukup berarti dari tayangan youtube podcast dengan kepercayaan penonton pada vaksin Covid 19.

\section{Kesimpulan}

Hasil penelitian menunjukkan bahwa terdapat pengaruh yang signifikan dari tayangan youtube podcast terhadap kepercayaan penonton pada vaksin Covid 19. Hal ini berarti bahwa penonton mempercayai tayangan youtube podcast Deddy Corbuzier sehingga penonton juga percaya bahwa vaksin yang dicampur tangani oleh Bill Gates merupakan konspirasi politik dan ekonomi dari para penguasa dunia. Hal ini karena Bill Gates memberikan sumbangan yang sangat besar terhadap pembuatan vaksin Covid 19, maka penonton mempercayai bahwa vaksin Covid 19 merupakan konspirasi sesuai dengan pesan yang disampaikan oleh Siti Fadilah dalam tayangan tersebut.

\section{Acknowledge}

Terima kasih kepada diri sendiri, dosen pembimbing artikel ilmiah, keluarga, dan teman-teman yang telah membantu dalam penulisan artikel ilmiah ini. Terima kasih atas segala bimbingan den semangat yang kalian berikan.

\section{Daftar Pustaka}

[1] Ambar. (2017, November 5). Teori Komunikasi Massa McQuail - Konsep - Karakteristik. Retrieved Juli 29, 2020, from Pakar Komunikasi: https://pakarkomunikasi.com/teorikomunikasi-massa-mcquail

[2] Arnus, S. H. (2015, November). Computer Mediated Communication (CMC), Pola Baru Berkomunikasi" Al-MUNZIR 8.2 (2018): 275-289. Al Munzir, VIII(2), 275 - 289.

[3] Boer, K. M. (2018, Desember). Interaktivitas sebagai Strategi Mediated Communication pada Fans Pages Starbucks Coffee Indonesia. Ilmu Komunikasi, X(2), 113 - 128.

[4] Christie, A. (2017). Interaktivitas Media Baru: Studi Kasus pada Tempo. Co. Diss. Universitas Multimedia Nusantara, 2017. Tangerang: Universitas Multimedia Nusantara.

[5] Dinata, E. F. (2020). Pengaruh Channel Youtube Horror Sara Wijayanto Terhadap Sikap Penonton Akan Hal-Hal Mistis. Medan: Universitas Medan Area.

[6] Hakim, A. F. (2016). Hubungan antara Tayangan Iklan Energen dengan Kesadaran Khalayak Untuk Sarapan Sehat di Pagi Hari. Bandung: Universitas Islam Bandung.

[7] Herlambang, A. A. (2020, Mei 13). Peneliti Media: Teori Konspirasi Bisa Berbahaya bagi Penanganan Covid-19. Retrieved Oktober 27, 2020, from https://www.ayosemarang.com/read/2020/05/13/56918/peneliti-media-teori-konspirasibisa-berbahaya-bagi-penanganan-covid-19 
[8] Jaynani, D. H. (2020, Februari 26). Media Sosial yang Paling Sering Digunakan di Indonesia (diakses Sabtu, 25 Juli 2020, 06:45). Retrieved Juli 25, 2020, from Databoks: https://databoks.katadata.co.id/datapublish/2020/02/26/10-media-sosial-yang-palingsering-digunakan-di-indonesia

[9] Kurnia, N. (2005). Perkembangan teknologi komunikasi dan media baru: Implikasi terhadap teori komunikasi. Mediator, VI(2), 291 - 296.

[10] Lievrouw, L. A. (2009). New media, mediation, and communication study. Information, Communication \& Society.

[11] McQuail, D. (2011). Teori Komunikasi Massa Edisi 6 Buku 1. Jakarta: Salemba Humanika.

[12] Media Indonesia. (2020, September 3). Deddy Corbuzier Youtuber Terkaya di Indonesia. Retrieved November 5, 2020, from Media Indonesia: https://mediaindonesia.com/read/detail/341711-deddy-corbuzier-youtuber-terkaya-diindonesia\#: : text=Akun\%20Youtube\%20Deddy\%20berpenghasilan\%20sekitar,lewat\%20k anal\%20Youtube\%20Baim\%20Paula

[13] Mondry, M. S. (2008). Pemahaman teori dan praktik jurnalistik. Penerbit Ghalia Indonesia. Penerbit Ghalia Indonesia.

[14] Mulya, Resti Aprida, Tandiyo Pradekso. (2018). Hubungan antara Motif Penggunaan Fitur LINE Today dan Interaktivitas Khalayak dengan Kepuasan Khalayak Menggunakan Fitur LINE Today. Interaksi Online, VI(4), 257 - 267.

[15] Mulyana, D. (2000). Ilmu komunikasi: suatu pengantar. Bandung: PT. Remaja Rosdakarya.

[16] Rofiq, A. (2007). Pengaruh Dimensi Kepercayaan (Trust) terhadap Partisipasi Pelanggan ECommerce. Malang: Universitas Brawijaya.

[17] Seputar Pengerahuan. (2018, Maret). Pengertian Media Sosial, Karakteristik, Fungsi, Jenis \& Dampaknya. Retrieved Juli 29, 2020, from Seputar Pengetahuan: https://www.seputarpengetahuan.co.id/2018/03/pengertian-media-sosial-karakteristikfungsi-jenis-jenis-dampak.html

[18] Thurlow, C., \& Laura Lengel, A. T. (2004). Computer mediated communication. Sage, 2004. New York: Sage.

[19] Yulianto, D. A. (2014). Hubungan Sosial Dalam Transaksi Ekonomi Pada Komunitas Virtual Pecinta Ikan Hias (Study Deskriptif Tentang Proses Pengembangan Kepercayaan Antar Anggota Dalam Proses Transaksi Jual Beli Ikan Hias Pada Komunitas Virtual Pecinta Ikan "O-Fish Forum"). Surabaya: Universitas Airlangga. 